\title{
Isolated Schwannoma of the Olfactory Groove: A Case Report
}

\author{
Luiz Augusto Nascimento ${ }^{1}$ Flávio Aurélio Parente Settanni ${ }^{1}$ José Franscisco de Góis Filho ${ }^{2}$ \\ Isabela Naria Dias Sanchez ${ }^{3}$ Bruna Barros Cavalcante ${ }^{4}$ João Noberto Stávale ${ }^{5}$
}

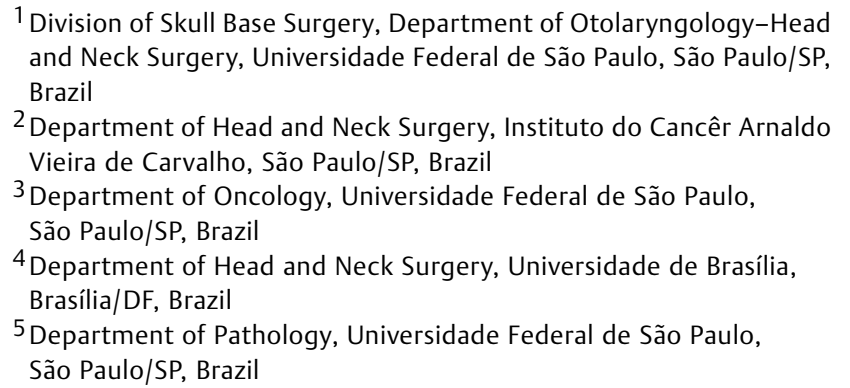

Address for correspondence Luiz Augusto Nascimento, MD, PhD, R. Estado de Israel, 493, apto 184, São Paulo/SP, CEP: 04022001, Brazil (e-mail: luizaugusto.hns@gmail.com).

Int Arch Otorhinolaryngol 2015;19:93-95.

\begin{abstract}
Introduction Schwannoma of the olfactory groove is an extremely rare tumor that can share a differential diagnosis with meningioma or neuroblastoma.

Objectives The authors present a case of giant schwannoma involving the anterior cranial fossa and ethmoid sinuses.

Case Report The patient presented with a 30-month history of left nasal obstruction, anosmia, and sporadic ipsilateral bleeding. Computed tomography of the paranasal sinuses revealed expansive lesion on the left nasal cavity extending to nasopharynx up to ethmoid and sphenoid sinuses bilaterally with intraorbital and parasellar extension to the skull base. Magnetic resonance imaging scan confirmed the expansive tumor

Keywords

- paranasal sinuses

- skull base

- neurilemmoma

- olfactory nerve

- head and neck neoplasms

- neoplasms

- nerve tissue without dural penetration. Biopsy revealed no evidence of malignancy and probable neural cell. Bifrontal craniotomy was performed combined with lateral rhinotomy (Weber-Ferguson approach), and the lesion was totally removed. The tumor measured $8.0 \times 4.3 \times 3.7 \mathrm{~cm}$ and microscopically appeared as a schwannoma composed of interwoven bundles of elongated cells (Antoni A regions) mixed with less cellular regions (Antoni B). Immunohistochemical study stained intensively for vimentin and S-100. Conclusion Schwannomas of the olfactory groove are extremely rare, and the findings of origin of this tumor is still uncertain but recent studies point most probably to the meningeal branches of trigeminal nerve or anterior ethmoidal nerves.
\end{abstract}

\section{Introduction}

Schwannoma of the olfactory groove is extremely rare. So far only 35 cases have been reported in the literature when we searched the PubMed database. Schwannoma had already been described at the beginning of the 19th century, but
Virchow was the first to recognize them for what they were. Such tumors account for $\sim 8 \%$ of all primary intracranial tumors. ${ }^{1}$ The most common arises from the vestibular portion of the eighth nerve and, less commonly, the fifth, ninth, tenth, and twelfth cranial nerves. ${ }^{1-6}$ They have been received

February 6, 2013

accepted

July 1,2013

published online

November 5, 2013
DOI http://dx.doi.org/

10.1055/s-0033-1353368. ISSN 1809-9777.
Copyright $\odot 2015$ by Thieme Publicações License terms

Ltda, Rio de Janeiro, Brazil 


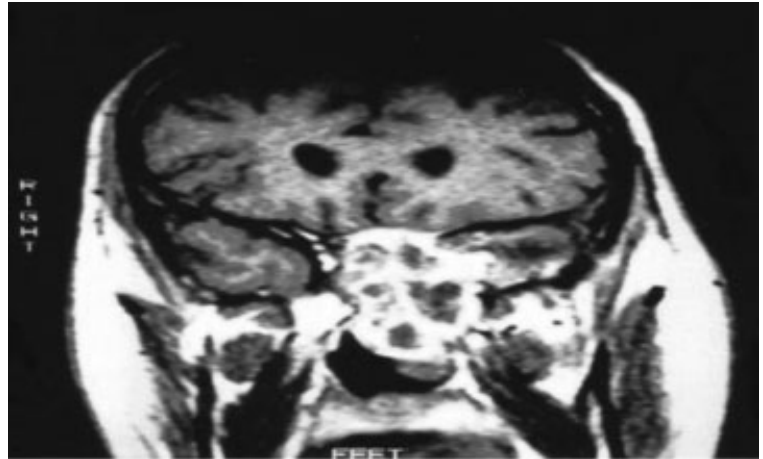

Fig. 1 Coronal magnetic resonance imaging showing extensive mass growing down from cribriform plate.

described as resembling subfrontal or olfactory groove schwannomas, which reflects their enigmatic origin. ${ }^{1-25}$

\section{Case Report}

The patient was a 39-year-old man with 30-month history of left nasal obstruction, anosmia, and sporadic ipsilateral bleeding. His physical examination showed a mass in the left nasal cavity extending to the nasopharynx. No café au lait spots or other signs of von Recklinghausen neurofibromatosis were observed.

Computed tomography of paranasal sinuses revealed expansive lesion on the left nasal cavity extending from the nasopharynx to ethmoid and sphenoid sinuses bilaterally with intraorbital and parasellar extension to the skull base. T2-weighted magnetic resonance imaging confirmed a heterogeneous hyperintense tumor occupying the anterior cranial fossa without dural penetration ( - Fig. 1). Biopsy by nasal endoscopy revealed no evidence of malignancy and probable neural cell. Cerebral angiography showed a large tumoral blush with pathologic vascularization of the displaced left maxillary artery and left ophthalmic artery without sufficient diameter for embolization.

The bilateral supraorbital approach was applied by making a coronal skin incision and retracting the scalp flap forward, and bilateral frontal craniotomy was performed with the John-Jane technique for excellent access to the floor of the anterior fossa and the superior orbits with less brain retraction. The orbital roof was partially removed and the dura was elevated on both sides of the crista galli. The tumor was seen arising from the base of the anterior cranial fossa and attached to the dura at level of the cribriform plate up to anterior clinoid process.

The lesion was well delineated, involving the anterior cranial fossa and parasellar region and extending down to the nasal cavity, nasopharynx, and ethmoid sinuses with intraorbital parasellar extension. The tumor was completely excised through the bifrontal craniotomy approach combined with lateral rhinotomy (Weber-Ferguson approach). The tumor measured $8.0 \times 4.3 \times 3.7 \mathrm{~cm}$ and was firm in consistency. Microscopically, the tumor appeared as a Schwannoma composed of interwoven bundles of elongated cells (Antoni A regions) mixed with less cellular regions (Antoni B). Immunohistochemical study stained intensively for vimentin and S-100 (-Fig. 2). The resected area

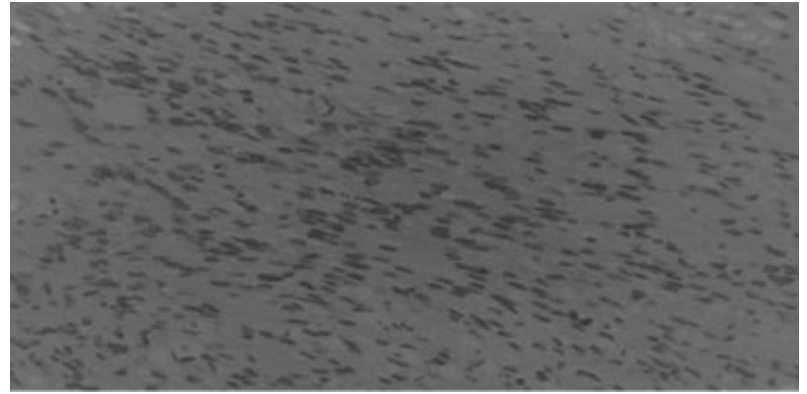

Fig. 2 Neopasm consisting of elongated spindle cells with poorly defined, palely eosinophil cytoplasm, sometime with nuclear palisading. Immunohistochemically, glial fibrillary acidic protein (GFAP) was negative and vimentin and S-100 protein stained intensively.

of the dura and tumor was repaired with part of the temporal bone and galea-periosteum aiming to minimize the possibility of fistula and infection. The patient remains free of disease with an excellent functional and cosmetic result. He is in good health with a residual sense of smell.

\section{Discussion}

Isolated schwannoma of the olfactory groove are rare tumors. ${ }^{13,14,35}$ According to a review by Ulrich et al in $1978,{ }^{36}$ three of the previous cases had been reported in association with von Recklinghausen neurofibromatosis. Husain et al reported a case of a tumor arising from the base of the right anterior cranial fossa, ${ }^{13}$ and Sabel and Teepen referred to a case of tumor of the anterior cranial fossa where the olfactory bulb and nerve were not seen. ${ }^{14}$

There are a few descriptions of intracerebral schwannomas. ${ }^{2-4,17,37-40}$ To date there are 35 cases of schwannoma of the anterior cranial fossa described in the literature. , $^{21}$

The origin of intracranial Schwannoma is intriguing. There are some hypotheses concerning their origin. Developmental theories hold that these lesions primarily arise from aberrant Schwann cells in the central nervous system. ${ }^{14,15,17,33}$ Russell and Rubinstein advocate that mesenchymal pial cells may transform into ectodermal Schwann cells, explaining the occurrence of intraparenchymal schwannomas. Other theories suggest an origin from multipotent mesenchymal cells or displacement of neural crest cells forming the focus of Schwann cells within brain parenchyma (schwannosis). ${ }^{35}$

The developmental theories can explain the origin of intraparenchymal schwannomas, ${ }^{14,15,18,33}$ but the subtype of schwannomas located in the anterior skull base intimately related to the olfactory groove seems to be an extra-axial tumor. $^{15,31,33}$

Adachi et al reviewed the literature in 2007 about the origin of schwannoma from the fila olfactoria. ${ }^{15}$ They reported that embryonic nerve, the plexus of dural vessels, and the fila olfactory that acquire Schwann cells have been considered as possible origins of these tumors. ${ }^{15,19}$ However, others authors have pointed that the olfactory schwannomas originate from the olfactory bulb and nerve. ${ }^{8,14,18,33}$ A kind of cell that expresses phenotypic features of both astrocyte and Schwann cell is present. ${ }^{19}$ 
To assess the possibility of schwannomas originating from a real peripheral nerve, we need to know which nerve, present near the olfactory bulb and first cranial nerve, could be the origin of the tumor growth. The anterior ethmoidal nerve and the ramus meningeus of the trigeminal nerve are possibilities $^{13,14,42}$ In most vertebrates, including man, a terminal nerve, which is part of an accessory olfactory system, is thought to be present. It is possible that this nerve is the source of an olfactory schwannoma.

The descriptions of the origin of this tumor are intriguing and enigmatic. Most descriptions point to a lesion intimately related to the anterior skull base, particularly the region of the olfactory groove.

\section{Conclusion}

Schwannomas represent $\sim 8 \%$ of all intracranial tumors. Schwannomas of the olfactory groove are extremely rare. The present case represents the 36th case described in the literature. The origin of this tumor is still uncertain but recent studies point most probably to the meningeal branches of trigeminal nerve or anterior ethmoidal nerves.

\section{References}

1 Auer RN, Budny J, Drake CG, Ball MJ. Frontal lobe perivascular schwannoma. Case report. J Neurosurg 1982;56(1):154-157

2 Gibson AA, Hendrick EB, Conen PE. Case reports. Intracerebral schwannoma. Report of a case. J Neurosurg 1966;24(2):552-557

3 Ramamurthy B, Anguli V, Iyer CGS. A case of intramedullary neurinoma. J Neurosurg 1958;27:92-94

4 Redekop G, Elisevich K, Gilbert J. Fourth ventricular schwannoma. Case report. J Neurosurg 1990;73(5):777-781

5 Amador AR, Santonja C, Del Pozo JM, Ortiz L. Olfactory schwannoma. Eur Radiol 2002;12(4):742-744

6 Sturm KW, Bonis G, Kosmaoglu V. [On a neurinoma of the cribriform lamina]. Zentralbl Neurochir 1968;29(4):217-222

7 Figueiredo EG, Soga Y, Amorim RL, Oliveira AM, Teixeira MJ. The puzzling olfactory groove schwannoma: a systematic review. Skull Base 2011;21(1):31-36

8 Choi YS, Sung KS, Song YJ, Kim HD. Olfactory schwannoma-case report-. J Korean Neurosurg Soc 2009;45(2):103-106

9 Bezircioğlu H, Sucu HK, Rezanko T, Minoğlu M. Nasal-subfrontal giant schwannoma. Turk Neurosurg 2008;18(4):412-414

10 Sano H, Hayashi Y, Hasegawa M, Yamashita J. Subfrontal schwannoma without hyposmia-case report. Neurol Med Chir (Tokyo) 2004;44(11):591-594

11 Nagao S, Aoki T, Kondo S, Gi H, Matsunaga M, Fujita Y. [Subfrontal schwannoma: a case report]. No Shinkei Geka 1991;19(1):47-51

12 Sato S, Toya S, Nakamura T, et al. [Subfrontal schwannoma: report of a case]. No Shinkei Geka 1985;13(8):883-887

13 Husain M, Mishra UK, Newton G, Husain N. Isolated olfactory groove neurilemmoma. Surg Neurol 1992;37(2):115-117

14 Sabel LH, Teepen JL. The enigmatic origin of olfactory schwannoma. Clin Neurol Neurosurg 1995;97(2):187-191

15 Adachi K, Yoshida K, Miwa T, Ikeda E, Kawase T. Olfactory schwannoma. Acta Neurochir (Wien) 2007;149(6):605-610, discussion 610-611

16 Saberi H, Khashayar P. Olfactory groove schwannoma masquerading as an orbital mass. Neurosciences (Riyadh) 2008;13(1):73-76

17 Frim DM, Ogilvy CS, Vonsattal JP, Chapman PH. Is intracerebral schwannoma a developmental tumor of children and young adults? Case report and review. Pediatr Neurosurg 1992;18 (4):190-194

18 Huang PP, Zagzag D, Benjamin V. Intracranial schwannoma presenting as a subfrontal tumor: case report. Neurosurgery 1997;40 (1):194-197

19 Yasuda M, Higuchi O, Takano S, Matsumura A. Olfactory ensheathing cell tumor: a case report. J Neurooncol 2006;76(2):111-113

20 Mirone G, Natale M, Scuotto A, Rotondo M. Solitary olfactory groove schwannoma. J Clin Neurosci 2009;16(3):454-456

21 Martínez-Soto L, Alfaro-Baca R, Torrecilla-Sardón MV, FernándezVallejo B, Ferreira-Muñóz R, De Diego T. [A new case of "olfactory schwannoma"; presentation and literature review]. Neurocirugia (Astur) 2009;20(3):294-297

22 Kanaan HA, Gardner PA, Yeaney G, et al. Expanded endoscopic endonasal resection of an olfactory schwannoma. J Neurosurg Pediatr 2008;2(4):261-265

23 Daglioglu E, Okay O, Dalgic A, Albayrak AL, Ergungor F. Cystic olfactory schwannoma of the anterior cranial base. $\mathrm{Br} J$ Neurosurg 2008;22(5):697-699

24 Yako K, Morita A, Ueki K, Kirino T. Subfrontal schwannoma. Acta Neurochir (Wien) 2005;147(6):655-657, discussion 657-658

25 Komoribayashi N, Arai H, Kojo T, Obonai C, Wakabayashi J, Ogawa A. [Subfrontal schwannoma: case report]. No Shinkei Geka 2005;33(6):601-605

26 Prasad D, Jalali R, Shet T. Intracranial subfrontal schwannoma treated with surgery and 3D conformal radiotherapy. Neurol India 2004;52(2):248-250

27 Shenoy SN, Raja A. Cystic olfactory groove schwannoma. Neurol India 2004;52(2):261-262

28 Murakami M, Tsukahara T, Hatano T, Nakakuki T, Ogino E, Aoyama T. Olfactory groove schwannoma-case report. Neurol Med Chir (Tokyo) 2004;44(4):191-194

29 Yuen A, Trost N, McKelvie P, Webster J, Murphy M. Subfrontal schwannoma: a case report and literature review. J Clin Neurosci 2004;11(6):663-665

30 de Souza HL, Ramos AM, Ramos CC, et al. [Olfactory groove schwannoma: case report]. Arq Neuropsiquiatr 2003;61(1):125-128

31 Carron JD, Singh RV, Karakla DW, Silverberg M. Solitary schwannoma of the olfactory groove: case report and review of the literature. Skull Base 2002;12(3):163-166

32 Tsai YD, Lui CC, Eng HL, Liang CL, Chen HJ. Intracranial subfrontal schwannoma. Acta Neurochir (Wien) 2001;143(3):313-314

33 Ahmad FU, Gupta A, Sharma MC, Shukla G, Mehta VS. The enigmatic origin of subfrontal schwannomas: report of a case without hyposmia. Acta Neurochir (Wien) 2006;148(6):671-672, discussion 672

34 Bando K, Obayashi M, Tsuneharu F. [A case of subfrontal schwannoma]. No Shinkei Geka 1992;20(11):1189-1194

35 Russell DS, Rubinstein LJ. Pathology of Tumors of the Nervous System. 3rd ed. London, UK: Edward Arnold; 1971:286

36 Ulrich J, Lévy A, Pfister C. Schwannoma of the olfactory groove. Case report and review of previous cases. Acta Neurochir (Wien) 1978;40(3-4):315-321

37 Ben Rhouma T, Bouzakoura C, Boudaouara MA, Mhiri C, Hentati K. [Intracerebral schwannoma. Apropos of a case]. Neurochirurgie 1988;34(2):123-127

38 Ghatak NR, Norwood CW, Davis CH. Intracerebral schwannoma. Surg Neurol 1975;3(1):45-47

39 Kasantikul V, Brown WJ, Cahan LD. Intracerebral neurilemmoma. J Neurol Neurosurg Psychiatry 1981;44(12):1110-1115

40 Vassilouthis J, Richardson AE. Subfrontal schwannoma. Report of a case. Acta Neurochir (Wien) 1980;53(3-4):259-266

41 Li YP, Jiang S, Zhou PZ, Ni YB. Solitary olfactory schwannoma without olfactory dysfunction: a new case report and literature review. Neurol Sci 2012;33(1):137-142

42 Viale ES, Pau A, Turtal S. Olfactory groove neurinomas. J Neurosurg Sci 1973;17:193-196 